\title{
Financing Constraints And Financial Development: Evidence From Selected African Countries
}

\author{
Letenah Ejigu Wale, University of South Africa (UNISA), South Africa
}

\begin{abstract}
Economic theory posits that financial development eases firm level financing constraints by mitigating information asymmetry and contracting imperfections. This paper empirically tests for this notion by using firm level data from selected African countries. The sampled firms show positive and significant investment cash flow sensitivity coefficients indicating they are financially constrained. Financial development is found to have a significant and negative effect on the estimated cash flow sensitivity coefficients indicating it reduces firm financial constraints. The result further shows that such positive role of financial development is attributed to financial intermediary development and not to stock market development. A unique result to the African reality is that even firms in countries with high level of financial development are financially constrained. This implies the financial development in Africa is too weak and more policy attention is needed in this regard.
\end{abstract}

Keywords: Financial Development; Financial Intermediary Development; Stock Market Development; Financing Constraints; African Countries

\section{INTRODUCTION}

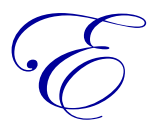

conomic theory predicts that financial development improves firms' access to external finance by mitigating information asymmetry and contracting imperfections that exist between the suppliers of finance and firms in need of the finance. External funds are generally thought to be costlier than internal finance because outsiders have less control over the borrower's actions (see for example, Jensen and Meckling, 1976) or because they know less about what the borrower will do with the funds (see Stiglitz and Weiss, 1981; Myers and Majluf, 1984). La Porta, Lopez-de-Silanes, Shleifer and Vishny (1997) are of the view that the problem of firm's access to finance is more severe in countries with weak financial development and weaker institutions that cannot properly protect investor's interests. In such situations, external finance will be more expensive than internal finance, and as a result, firms will be financially constrained. Under the case of financial constraints, a firm's investment (and ultimately growth) is more likely to be limited by the available internal resources.

The extant research provides evidence consistent with the theoretical prediction. Rajan and Zingales (1998) empirically found that an increase in financial development will induce a bigger impact on industrial growth if the industry heavily depends on external finance than if the industry is not naturally a heavy user of external finance. In this way, financial development reduces the financing constraints of firms that are dependent on external finance. Demirguc-Kunt and Maksimovic (1998) find that firm growth financed by external finance (i.e. long-term external debt and equity) is positively associated with the level of a country's financial development. Love (2003) finds that financial development affects firm investments through its impact on firms' cost of capital. Her results also support the view that financing constraints decrease with financial market development. Wurgler (2000) also shows that financial development improves the capital allocation process and found that countries with higher levels of financial development increase investment more in growing industries and decrease investment more in declining industries than financial underdeveloped economies. 
Despite the above points, Tseng (2012) further suggested that financial development might have some adverse effects. He claims that much of financial development is due to financial liberalization and the latter is reported to have caused excess volatility and instability in the capital markets (Bae, Chan and Ng, 2004; Stiglitz, 2004). Such instability may make raising external finance difficult for firms.

From the foregoing, it is clear that the notion that financial development eases the financing constraints of firms is an unsettled empirical issue. It is against this background this paper investigates the issue using firm level data of selected African countries. Most studies in this area focus on developed countries (Love, 2003; Becker and Sivandasany, 2010; Baum, Schafer, Talavera, 2011; Islam and Mozumdar, 2007; Khurana, Martin \& Pereira, 2006; Semenov, 2006). Since financial development and the financial constraints faced by firms differ across countries and regions, an empirical study of African countries might be insightful. Financial development in Africa is too low (see Misati and Nyamongo, 2011; Yartey and Adjasi, 2007; Allen, Otchere and Senbet, 2011) and hence the extent of firm financial constraints is perceived to be high.

The rest of the paper is organized as follows. Section two discuss the relevant literature which focus on the role of financial systems in general, the relative merit of bank based and market based financial system, and a glimpse on African financial system. Section 3 discusses the data and methodology section whereas the result and discussion are addressed in section four. The last section five concludes the paper.

\section{REVIEW OF LITERATURE}

The literature dealing with the issue of whether financial development reduces financial constraints is related to broad macro and micro literature that tries to relate financial development with economic growth. At the macro-level, the issue of whether financial development helps economic growth is largely a contested one. Early economists such as Schumpeter (1911) said finance is helpful for growth whereas Robinson (1952) claims of reverse causality. King and Levine (1993) are of the view that finance is still important for economic growth.

At the micro level, Modigliani \& Miller (1958) showed that in the world of perfect capital markets, finance is irrelevant for investment decisions. Firms can easily substitute external finance for internal finance. However, the assumption of a perfect capital market is rather an utopian idea than a practical reality. Frictions due to information asymmetry and agency costs create a divergence between the costs of external and internal funds, thereby constraining firms in their ability to fund investment projects. As a result, many later studies showed finance is relevant for firm investment and thereby aggregate economic growth (see Hubbard, 1998 for a survey).

Overall, even if the finance-growth nexus is a highly debated topic, the dominant view is that finance is important for economic growth (see Levine, 2005 for a detailed discussion). Now the question is how finance assists growth. One of the channels through which finance helps growth is by reducing firm level financing constraints. Specifically financial development mitigates information asymmetry and contracting imperfections, which create a wedge between the cost of internal and external finance. Under the situation of relaxed credit constraints, firms can invest optimally and bring the needed economic growth.

\section{The Functions of a Financial System}

The extensive review by Levine (2005) shows that financial system provide the following key functions, which helps for economic growth. They produce information ex ante about possible investments and allocate capital; monitor investments and exert corporate governance after providing finance; facilitate the trading, diversification, and management of risk; mobilize and pool savings; ease the exchange of goods and services. The first two functions are very important for firms' access to finance and we discuss them at some length. ${ }^{1}$

Without intermediaries each investor would face the large fixed cost associated with evaluating firms, managers, and economic conditions (Boyd and Prescott, 1986). By improving information on firms, managers, and economic conditions, financial intermediaries can accelerate economic growth. Assuming that many entrepreneurs

\footnotetext{
${ }^{1}$ For a detailed discussion of the other functions of the financial system, see Levine (2005). 
solicit capital and that capital is scarce, financial intermediaries that produce better information on firms will thereby fund more promising firms and induce a more efficient allocation of capital (Greenwood and Jovanovic, 1990). Allen (1990) also develops models where financial intermediaries arise to produce information on firms and sell this information to savers.

Without effective governance, providers of capital may hesitate to extend finance to firms. For instance stock markets enable in better governance (align the interest of owners and managers) by linking managerial compensation to stock prices (Jensen and Murphy, 1990). Further the threat of takeover aligns managerial interest with owners in well-developed stock markets (Stein, 1988).

Debt contracts also may lower the cost of monitoring firm insiders and thereby improve corporate governance. Using Jensen's "free cash flow argument", Aghion, Dewatripont and Rey (1999) show that debt instruments reduce the amount of free cash available to firms. This in turn reduces managerial slack and accelerates the rate at which managers adopt new technologies.

Financial intermediaries such as banks also improve governance. Diamond (1984) develops a theoretical model in this regard. The intermediary mobilizes the savings of many individuals and lends these resources to firms. This "delegated monitor" economizes on aggregate monitoring costs and eliminates the free-rider problem since the intermediary does the monitoring for all the investors.

The two basic functions of financial systems in solving information asymmetry and corporate governance are very critical to firms' access to finance. Empirical evidence in this regard i.e. the role of financial development in relaxing credit constraints is found by Rajan and Zingales (1998), Love (2003), Becker and Sivandasany (2010), Baum et al. (2011), Islam and Mozumdar (2007), Khurana et al.(2006), Semenov (2006), Tseng (2012).

Furthermore, financial development has other benefits. It facilitates the allocation of credit to profitable firms and those firms with good investment opportunities (Bertrand, Schoar and Thesmar, 2007). It also helps the firms to grow faster (Demirguc-Kunt and Maksimovic, 1998).

In sum it is reasonable to expect that firms in countries with more developed financial systems to be less financially constrained than firms in countries with less developed financial systems. With more access to external finance, firms will invest optimally. This leads to firms' growth, which in turn is translated into aggregate economic growth.

\section{Bank vs. Market Based Financial Systems}

Financial development can be broadly the result of financial intermediary development (such as banks) and stock market development. There is a much debate on whether bank based or market based financial systems are good for the economy. ${ }^{2}$ Below is an extract of some of the debates between bank vs. market based financial systems.

The case for a bank-based system: This view argues against the market based financial system. Since stock markets reveal information quickly to investors at large, there is a lack of incentive on individual investors from devoting resources towards researching firms. Thus greater market development may actually impede incentives for identifying innovative projects for faster growth (Stiglitz, 1985). Banks can mitigate the potential disincentives from efficient markets by privatizing the information they acquire and by forming long-run relationships with firms (Boot, Greenbaum and Thakor, 1993). Banks can make investments without revealing their decisions immediately in public markets and this creates incentives for them to research firms, managers, and market conditions with positive ramifications on resource allocation and growth. Furthermore, Rajan and Zingales (1999) emphasize that powerful banks with close ties to firms may be more effective at exerting pressure on firms to re-pay their debts than atomistic markets.

\footnotetext{
${ }^{2}$ For a detailed theoretical and empirical review of this debate, see Levine (2005). 
On corporate governance, a large literature stresses that markets do not effectively monitor managers (Shleifer and Vishny, 1997). Takeovers may not be an effective corporate control device because insiders have better information than outsiders. Furthermore, stock market liquidity may encourage a myopic investor climate. In liquid markets, investor can inexpensively sell their shares, so that they have fewer incentives to undertake careful and expensive - corporate governance (Bhide, 1993). Thus, greater stock market development may hinder corporate governance and induce an inefficient allocation of resources according to the bank-based view.

The case for a market-based system: This view argues against the bank based financial system. Once banks acquire substantial, inside information about firms, they can extract rents from firms; firms must pay for their greater access to capital (Hellwig, 1991). Banks - as debt issuers - also have an inherent bias toward prudence, so that bank based systems may confound corporate innovation and growth (Morck and Nakamura, 1999). Allen and Gale (1999) also observe that banks may not be effective gatherers and processors of information in new, uncertain situations involving innovative products and processes.

Banks are also attacked on effectiveness of corporate governance systems. Bankers act in their own best interests, not necessarily in the best interests of all creditors or society at large. For instance, influential banks may prevent outsiders from removing inefficient managers if these managers are particularly generous to the bankers (Black and Moersch, 1998).

Rajan and Zingales (2003) argue that in response to adverse shocks that affect the economy unevenly, market-based systems will more effectively identify, isolate, and bankrupt truly distressed firms and prevent them from hurting the overall economy than a bank-based system.

Countervailing Views to Bank-Based vs. Market-Based Debate

Some reject the importance of the bank-based versus market-based debate and instead argue that the issue is overall financial development, not the particular institutional arrangements that provide financial services to the economy (Merton and Bodie, 2004; Levine, 1997). According to this view, the crucial issue for growth is whether the economy has access to a well-functioning financial system; the exact composition of the financial system is of secondary importance.

On the empirical side, many authors found that those firms working in predominantly market based financial system are more constrained than those in bank based financial system (see the findings by Baum et al., 2011; Semenov, 2006; Tseng 2012; Bond, Elston, Mairesse, and Mulkay, 2003). Tseng (2012) is of the view that firms are more constrained in market based financial systems because stock market development may induce excess volatility, other risks and add uncertainty to firm financing.

\section{African Financial System}

Traditional banking and informal finance dominate the financial system of most African countries. On banking development, the sector is dominated by state owned banks or few large, mainly foreign banks. As part of restructuring programs and privatizations, reforms were meant to improve the quality of the banks. Despite this, the ratio of private credit to GDP in Africa has been declining steadily and many banks still invest heavily in the safer government treasury bills (Allen et al., 2011). Misati \& Nyamongo (2011) attributed the declining private credit to stringent collateral requirements imposed by banks, information asymmetry and the huge public sector in the banking industry, which persisted in some Africa countries even after liberalization.

On stock market development, Yartey and Adjasi, (2007) are of the view that Sub-Saharan Africa (SSA) stock markets are still small with few listed companies and low market capitalization. Only South Africa has a relatively better-developed stock market. Besides, Allen et al. (2011) observe that many of African stock markets are thin and illiquid. 


\section{DATA AND METHODOLOGY}

Firm level data is collected from Orbis, a financial database maintained by the Bureau van Djik. On the other hand, country level financial development data is collected from the World Bank's Global Financial Development Indicators Database. Six African countries with relatively better financial development are selected. These include Egypt, Kenya, Morocco, Nigeria, South Africa and Tunisia (Starkey, 2010). Countries with high financial development are selected due to data availability concerns.

Firm level data is available for a period of 10 years (2004-2013) from the Orbis website whereas the World Bank country level data is available for many years as early as 1960 up to 2011 . Due to the need to merge the two data sets and after some data cleaning, the useable final dataset is reduced to 7 years (2005-2011), consists of 273 firms and 1574 firm-year observations. The number of firms-year observations is further reduced to 854 due to the use of Generalized Method of Moments (GMM) estimation. Consistent with prior studies on investment cash flow sensitivity, data is taken from manufacturing companies only.

Egypt and South Africa have the highest number of firms (98 and 94 firms respectively) whereas the rest countries are least represented, especially Kenya and Tunisia have only 12 and 6 firms respectively in the final dataset. Data is available for an average of 6 years with Tunisia having the full 7 years data from whereas Nigeria and Kenya having 5 years data.

The following data cleaning procedures are employed. First, consistent with Baum et al. (2011) firms that are engaged in significant mergers and acquisitions, and divestiture activities are removed. The growth rate of assets is calculated and if a firm-year observation has a growth rate that exceed $85 \%$, it is trimmed (removed) from the dataset. Second, all firm level variables are winsorized at the $1 \%$ and $99 \%$ percentile, i.e. all outliers are replaced with these percentile values. Third, those firms-year observations with negative assets values are dropped.

Financing constraints are measured using the framework of Fazzari, Hubbard and Peterson (1988) that employs the sensitivity of investment to cash flow, with higher sensitivity interpreted as evidence of financing constraints. Although such approach is widely used, it is subject to some critics. The notable ones are those by Kaplan and Zingales (1997) who found that least constrained firms shows higher investment cash flow sensitivity. They attribute their result to managerial risk aversion rather than financing constraints. They said, even if least constrained firms can raise external finance easily, they still prefer internal finance due to managerial risk aversion and irrational behavior. Furthermore, investment and cash flow can be highly related even for the least constrained firms due to the agency cost of free cash flow. If managers are not properly monitored, they may waste free cash flows in unproductive investment. Despite such caveats, the approach of Fazzari et al. (1988) is still dominant in empirical research and used in our paper.

Two models are used to estimate the investment cash flow sensitivity coefficients: the Q model and Euler Equation approach (George, Kabirb \& Qianc, 2011). The Q model has the advantage of measuring directly the expected value of future profitability. But the $\mathrm{Q}$ model is not good if stock market prices are not efficient. The commonly used average $\mathrm{Q}$ can be an imprecise proxy for the value of an additional unit of new capital (marginal Q). Furthermore, the use of Q may overestimate the cash flow sensitivity coefficient because cash flow may contain information about investment opportunities that were not captured by Q (Carreira \& Silva, 2013). In a model where financial frictions are absent, Alti (2003) showed that even if Q is corrected firms exhibit positive ICFS. Guariglia (2008) is also of the view that the Q-model suffers from misspecification problems. The Euler equation model exploits the relationship between investments in successive time periods and has the advantage that it doesn't require explicit use of future values.

In view of the shortcomings of the Q model, this paper uses the Euler equation approach. Taking insights from Carreira \& Silva (2013) and Guariglia (2008) and with some modifications, the basic econometric model that tests for the sensitivity of investment to cash flow is given by: 


$$
\left(\frac{I_{i t}}{K_{i t-1}}\right)=\alpha+\beta_{1}\left(\frac{I_{i t-1}}{K_{i t-2}}\right)+\beta_{2} \Delta S+\beta_{3}\left(\frac{C F_{i t}}{K_{i t-1}}\right)+f_{i}+d_{c}+d_{t}+e_{i t}
$$

Where: $I$ is investment measured as the difference between net property, plant and equipment at the end of the period and beginning of the period plus depreciation; $K$ is the capital stock or net property, plant and equipment; $\Delta S$ is the natural logarithm of sales growth; $C F$ is cash flow measured as Net Income plus Depreciation; $f i$ represents firm fixed effects, $d c$ represents country dummies and $d t$ represents time dummies. Time dummies are added because investment and financing behaviours of firms are also influenced by macro-economic factors including the business cycle. Finally, eit is the error term.

To test our main hypothesis of interest i.e. the role of financial development in reducing firm level financial constraints, the cash flow variable is interacted with the different financial development measures. These measures include overall Financial Development (FD) and its components Stock Market development (STKMKT) and Financial Intermediary development (FININT). This interaction terms regression approach and the measures are is consistent with Love (2003) and Tseng (2012).

$$
\left(\frac{I_{i t}}{K_{i t-1}}\right)=\alpha+\beta_{1}\left(\frac{I_{i t-1}}{K_{i t-2}}\right)+\beta_{2} \Delta S+\beta_{3}\left(\frac{C F_{i t}}{K_{i t-1}}\right)+\beta_{4}\left(\frac{C F_{i t}}{K_{i t-1}}\right) *(\text { FDMeasures })+f_{i}+d_{c}+d_{t}+e_{i t}
$$

FD Measures stands for FD, STKMKT and FININT. The overall financial development (FD) is calculated as the sum of STKMKT and FININT. The STKMKT measure in turn is calculated as the average of the standardized values of market capitalization to GDP ratio, value traded to GDP ratio and turnover (i.e. value traded to market capitalization) ratio. By standardized value it means all the raw data is converted into Z-scores having a mean of 0 and standard deviation of 1 . The FININT measure is calculated as the average of the standardized values of liquid liabilities (M3) to GDP ratio and private credit to GDP ratio. Since the use of M3 to GDP ratio may be sometimes problematic as a measure of FININT, alternative measure of the ratio of money and quasi money (M2) to GDP ratio was used. But the results remain qualitatively similar as M2 and M3 are highly correlated ( $r=0.8912$, significant at $5 \%$ ).

To check the validity of equation 2 results and test a further hypothesis of firms' financial constraint across the different degree of financial development measures, equation 3 is estimated. In this equation, the different financial development measures are split into low and high FD (STKMKT) (FININT) based on median values. Those firms below the median values are classified as operating in a country with low financial development measures and firms above the median values are operating in a country with relatively high financial development measures. The median values are $0.24,0.03$ and 0.23 respectively for the FD, STKMKT and FININT measures. Then dummy variables are created for these firm classifications as follows. If a firm is operating in country with low financial development measures, it is given a code of 1, zero otherwise. This variable is labelled as "low FD, low STKMKT and low FININT". The same procedure is used to create the dummy variable for "high FD, high STKMKT and high FININT". After the dummies are created, they are interacted with cash flow. Equation 3 captures this sample split econometric specification.

$$
\left(\frac{I_{i t}}{K_{i t-l}}\right)=\alpha+\beta_{1}\left(\frac{I_{i t-1}}{K_{i t-2}}\right)+\beta_{2} \Delta S+\beta_{3}\left(\frac{C F_{i t}}{K_{i t-l}}\right)+\beta_{4}\left(\frac{C F_{i t}}{K_{i t-l}}\right) *(\text { FDMeasuresCategory })+f_{i}+d_{c}+d_{t}+e_{i t}
$$

FDMeasuresCategory represent the low and high FD(STMKMKT)(FININT) categories.

As to the estimation technique, the system GMM estimator, which is a version of dynamic panel model estimators, is used. Previous authors such as Love (2003) and Baum et al. (2011) used such estimators in studying the effect of financial development on firm level financing constraints. 
As Roodman (2009) explains dynamic panel estimators are designed for the following situations, 1) "small $\mathrm{T}$, large " panels meaning few time periods and many individuals; 2) a linear functional relationship; 3) a single left hand side variable that is dynamic, depending on its own past realizations; 4) independent variables that are not strictly exogenous meaning correlated with past and possibly current realization of the error; 5) fixed individual effects; 6) heteroskedasticity and autocorrelation within individuals but not across them.

There are two kinds of dynamic panel estimators, Difference GMM and System GMM (Roodman, 2009). The difference GMM (also called Arellano-Bond estimator) transforms all regressors by first differencing and then apply the Generalized Method of Moments technique. The system GMM (Arellano-Bover or Blundell-Bond estimator) augments the Arellano-Bond estimators by making an additional assumption that the first difference of instrument variables is uncorrelated with the fixed effect. This allows the introduction of more instruments and dramatically improves efficiency. It builds a system of two equations, the original equation as well as the transformed one through first differencing, and is known as system GMM.

Our data set stratifies most of the criteria listed above to use dynamic panel estimators. Our panel is short where there is small $\mathrm{T}$ and large $\mathrm{N}$. Our specification is also linear. Investment is modelled as function of its own lag. The fixed effect (within effect) model estimators are inconsistent once lagged regressors are introduced. This is

because the within model will have the first regressors $y_{i t-1}-\bar{y}_{i}$ that is correlated with the error $\varepsilon_{i t-1}-\bar{\varepsilon}_{i}$. This correlation happens because $y_{i t-1}$ is correlated with $\varepsilon_{i t-1}$ and hence with $\bar{\varepsilon}_{i}$. Furthermore, instrumental variable estimation using lags is not possible because any lag of $y_{i t}$ will be correlated with $\bar{\varepsilon}_{i}$ and hence with $\varepsilon_{i t-1}-\bar{\varepsilon}_{i}$. By contrast, although the first difference estimator is also inconsistent, instrumental variable estimators of the first difference model that use appropriate lag of $y_{i t}$ as instruments do lead to consistent parameter estimates (Cameroun and Trivedi, 2009). In our model, some of the explanatory variables such as cash flow are endogenous. Cash flow is considered endogenous because both cash flow and investment are simultaneously determined by profitability (Islam and Mozmudar, 2007).

As to some of the specification tests used in our estimation, robust standard errors are employed to address the issues of heteroskedasticity. Autocorrelation of order 2, AR (2), test is used to check for autocorrelations in first difference errors. Two lags of the right hand side variables are used as instruments. The Sargan test of overidentifying restriction is used to test for instrument validity.

\section{RESULTS AND DISCUSSION}

\section{Descriptive Statistics}

The descriptive statistics is discussed under two section. The first deals with statistics of key variables by different degree of financial development and the second deals with statistics of key variables by the sample African countries.

Table 1 below presents the descriptive statistics of main variables by different degree of financial development. 
Table 1. Descriptive Statistics (Mean) by key variables by financial development

\begin{tabular}{lcccccccc}
\hline \multirow{2}{*}{ Variables } & \multicolumn{2}{c}{ Cash flow } & \multicolumn{2}{c}{ FD } & \multicolumn{2}{c}{ STKMKT } & \multicolumn{2}{c}{ FININT } \\
\cline { 2 - 9 } & Low & High & Low & High & Low & High & Low & High \\
\hline Investment & 0.2 & 0.66 & 0.5 & 0.41 & 0.5 & 0.4 & 0.5 & 0.4 \\
Sales growth & 0.1 & 0.18 & 0.1 & 0.19 & 0.1 & 0.18 & 0.1 & 0.18 \\
Cash flow & 0.1 & 7.81 & 4 & 3.98 & 4 & 4 & 4.1 & 3.91 \\
Firm-Year (NT) & 781 & 793 & 703 & 871 & 783 & 791 & 704 & 870 \\
\hline
\end{tabular}

High cash flow firms have the highest investment rates and sales growth. Since they are not financially constrained, they are expected to invest more. Investment is higher in countries having low FD whereas sales growth is higher in countries with higher FD. This possibly indicates production is located in low cost and less developed economies whereas the products are sold in relatively developed markets. Cash flow is not different between countries with high or low FD. The descriptive statistics of the key variables when samples are split by STKMKT and FININT are the same as that of the FD sample split.

Table 2 discuss the descriptive statistics of key variables by the sampled six African countries.

Table 2. Descriptive Statistics (Mean) of key variables by country

\begin{tabular}{llllllll}
\hline Country / Variables & Investment & Sales Growth & Cash Flow & FD & STKMKT & FININT & NT \\
\hline Egypt & 0.33 & 0.13 & 4.8 & -0 & -0.14 & 0.13 & 585 \\
Kenya & 0.62 & 0.17 & 2.89 & -2 & -1.14 & -0.83 & 64 \\
Morocco & 0.3 & 0.13 & 1.55 & 0.04 & -0.56 & 0.61 & 150 \\
Nigeria & 0.89 & 0.18 & 5.77 & -2.3 & -1.07 & -1.18 & 200 \\
South Africa & 0.44 & 0.2 & 3.53 & 1.55 & 1.2 & 0.34 & 536 \\
Tunisia & 0.15 & 0.03 & 0.29 & -1.3 & -1.11 & -0.22 & 39 \\
Overall Mean & 0.44 & 0.16 & 3.99 & 0.13 & 0.1 & 0.03 & 1574 \\
\hline
\end{tabular}

In terms of investment, Nigeria and Kenya has the highest investment rate (above the overall mean investment rate of 0.44) whereas Tunisia is the least. On sales growth, South Africa, Nigeria and Kenya are the highest (above the overall mean) and again Tunisia is the lowest. On cash flow, Nigerian and Egyptian companies have the highest cash flow and again Tunisian companies are the least. On financial development and stock market development measures, South Africa is a clear outlier whereas Nigeria has the lowest FD and Kenya has the lowest STKMKT. Finally on financial intermediary development Morocco, South Africa and Egypt have the highest values whereas Nigeria is the least.

From these results, it can be seen that Nigeria has weak financial development. This may indicate that most financing may come from informal finance. The realities in Kenya are closer to Nigeria. The real sector is growing, but the financial sector especially stock markets are weak. Tunisia suffers from weak real sector development. South Africa has a developed financial system, but it is surprisingly surpassed by Morocco on financial intermediary development.

\section{Correlations}

Table 3 present the correlation among key variables to highlight any multicollinearity issue.

Table 3. Correlation among Key Variables

\begin{tabular}{lcccccc}
\hline \multicolumn{1}{c}{ Variables } & Investment & Sales Growth & Cash Flow & FD & STKMKT & FININT \\
\hline Investment & 1 & & & & & \\
Sales Growth & $0.1215^{* *}$ & 1 & & & & \\
Cash Flow & $0.4824^{* *}$ & 0.0462 & 1 & 1 & & \\
FD & $-0.1158^{* *}$ & 0.0416 & -0.0384 & $0.9458^{* *}$ & 1 & \\
STKMKT & $-0.0761^{* *}$ & $0.0661^{* *}$ & -0.0319 & $0.8516^{* *}$ & $0.6352^{* *}$ & 1 \\
FININT & $-0.1526^{* *}$ & -0.0078 & -0.04 & & \\
\hline
\end{tabular}


Investment is positively and significantly correlated with sales growth and cash flow suggesting the accelerator effect and financing constraints respectively. Surprisingly, investment is negatively and significantly correlated with all of the financial development measures. Sales growth is not correlated with most of the variables except stock market development. Cash flow is not significantly correlated with any of the financial development measures.

As expected the financial development measure is highly correlated with its components, stock market development and financial intermediary development. The two financial development components are also highly correlated indicating countries having developed banking system have a developed stock market or vice versa. In general, multicollinearity among the main explanatory variables such as sales growth, cash flow and FD measures is not an issue to be concerned about as the correlations are not high among these variables.

\begin{tabular}{|c|c|c|c|c|c|c|c|c|c|c|c|c|c|c|}
\hline \multirow{3}{*}{ Variables } & \multirow{2}{*}{\multicolumn{2}{|c|}{$\begin{array}{c}\begin{array}{c}\text { Without } \\
\text { Interaction }\end{array} \\
\text { All CF }\end{array}$}} & \multicolumn{4}{|c|}{ CF* FD Interaction } & \multicolumn{4}{|c|}{$\mathrm{CF}^{*}$ STKMKT Interaction } & \multicolumn{4}{|c|}{ CF* FININT Interaction } \\
\hline & & & \multicolumn{2}{|c|}{ Overall FD } & \multicolumn{2}{|c|}{$\begin{array}{c}\text { FD Sample } \\
\text { Splits } \\
\end{array}$} & \multicolumn{2}{|c|}{$\begin{array}{c}\text { Overall } \\
\text { STKMKT } \\
\end{array}$} & \multicolumn{2}{|c|}{$\begin{array}{c}\text { STKMKT } \\
\text { Sample Splits } \\
\end{array}$} & \multicolumn{2}{|c|}{$\begin{array}{c}\text { Overall } \\
\text { FININT } \\
\end{array}$} & \multicolumn{2}{|c|}{$\begin{array}{c}\text { FININT } \\
\text { Sample Splits }\end{array}$} \\
\hline & Coeff. & P-val. & Coeff. & P-val. & Coeff. & P-val. & Coeff. & P-val. & Coeff. & P-val. & Coeff. & P-val. & Coeff. & P-val. \\
\hline Lagged investment & 0.14 & 0.154 & 0.11 & 0.088 & 0.08 & 0.285 & 0.1 & 0.094 & 0.1 & 0.241 & 0.012 & $0.032 * *$ & 0.1 & 0.223 \\
\hline Ln Sales growth & 0.03 & 0.263 & 0.03 & 0.143 & 0.02 & 0.275 & 0.03 & 0.162 & 0.02 & 0.316 & 0.02 & 0.154 & 0.01 & 0.82 \\
\hline Cash flow & 0.04 & $0.000 * *$ & 0.05 & $0.000 * *$ & & & 0.05 & $0.000 * *$ & & & 0.049 & $0.000 * *$ & & \\
\hline Cash flow $*$ Overall FD & & & -0.01 & $0.040^{* *}$ & & & & & & & & & & \\
\hline Cash flow $*$ Low FD & & & & & 0.09 & $0.000 * *$ & & & & & & & & \\
\hline Cash flow $*$ High FD & & & & & 0.03 & $0.002 * *$ & & & & & & & & \\
\hline Cash flow * Overall STKMKT & & & & & & & -0.01 & 0.382 & & & & & & \\
\hline Cash flow $*$ Low STKMKT & & & & & & & & & 0.04 & $0.009 * *$ & & & & \\
\hline Cash flow $*$ High STKMKT & & & & & & & & & 0.05 & $0.000 * *$ & & & & \\
\hline Cash flow $*$ Overall FININT & & & & & & & & & & & -0.05 & $0.026 * *$ & & \\
\hline Cash flow $*$ Low FININT & & & & & & & & & & & & & 0.07 & $0.000 * *$ \\
\hline Cash flow $*$ High FININT & & & & & & & & & & & & & 0.04 & $0.004 * *$ \\
\hline \multicolumn{15}{|l|}{ Difference between coefficients } \\
\hline $\begin{array}{l}\text { CF Low FD/STKMKT/FININT = } \\
\text { CF High FD/STKMKT/FININT }\end{array}$ & & & & & & $0.004 * *$ & & & & 0.536 & & & & $0.040 * *$ \\
\hline Wald (p-value) & & $0.000 * *$ & & $0.000 * *$ & & $0.000 * *$ & & $0.000 * *$ & & $0.000 * *$ & & $0.000 * *$ & & $0.000 * *$ \\
\hline Sargan (p-value) & & 0.332 & & 0.228 & & 0.441 & & 0.294 & & 0.54 & & 0.2 & & 0.598 \\
\hline AR (2) (p-value) & & 0.771 & & 0.675 & & 0.997 & & 0.673 & & 0.675 & & 0.827 & & 0.586 \\
\hline $\begin{array}{ll}\mathrm{NT} \\
\mathrm{N}\end{array}$ & \multicolumn{14}{|c|}{854} \\
\hline
\end{tabular}

Notes: Country and time dummies are included, but for brevity purpose the result is not reported

$* *$ significant at $5 \%$ 


\section{Econometric Results}

As highlighted in the methodology section the system GMM estimators are employed, which are more efficient than the difference GMM estimators. These estimators are relevant in our case since the lagged dependent variable is included in the model and some of the explanatory variables such as cash flow are not strictly exogenous. Before interpreting the main result, let us highlight the model adequacy results. The Wald statistics is significant indicating all the included variables jointly explain the investment behaviour of firms in the selected African countries. The Sargan test is insignificant indicating the included instruments of two lags are valid. The AR (2) test is also insignificant indicating there is no autocorrelation in the first difference residuals and thus no specification problem in the model. All standard errors are robust to address the issue of heteroskedasticity.

\section{Investment Equations without Interactions}

This equation is estimated with lagged investment, sales growth and cash flow as explanatory variables. The result indicated that lagged investment is not significant except in the model for cash flow interaction with the overall FININT. This indicates there is no persistence in the investment decision of firms. Current year investment doesn't depend on what happened in last year. Other exogenous factors are affecting investment rather than internal decisions of the firms. Sales growth is also insignificant indicating demand for firms' products is not the driving force behind firms' investment. The main variable of interest to this research is cash flow and it is found to have a positive and significant effect on firm investment. A $10 \%$ increase in cash flow leads to a $4 \%$ increase in firm investment. According to Fazzari et al. (1988), such positive and significant cash flow coefficient shall be interpreted as evidence of financial constraints. But the caveats to such interpretation shall not be ignored.

\section{Investment Equations with FD Interactions}

In this equation, cash flow is interacted with the overall FD index and the FD sample splits (low and high FD categories). Like the previous result, the level cash flow term is again significant indicating a higher investment cash flow sensitivity, which can be interpreted as the existence of financing constraints in the overall sample. The cash flow interaction with overall FD shows a negative and significant coefficient. This indicates that financial development reduces the investment cash flow sensitivity coefficients, which are a measure of financing constraints.

When the cash flow variable is interacted with the FD sample splits (low and high FD groups), the result indicates that firms in both low and high FD countries show significant and positive cash flow coefficient. This indicates that both groups of firms are financially constrained. This is not surprising in Africa where the overall financial development is too low and even makes firms in countries with high FD financially constrained.

Furthermore, chi-square tests are conducted for any significant differences between the cash flow coefficients of low and high FD groups. The result shows that there is indeed significant difference $(9 \%$ is greater than 3\%) between the two groups. This indicates that firms in countries with high FD are less financially constrained than firms in countries with low FD. Such result reaffirms the original results of cash flow interaction with overall $\mathrm{FD}$ in that financial development indeed reduces financing constraints.

\section{Investment Equations with STKMKT Interactions}

Like the FD regressions, cash flow is interacted with the overall STKMKT index and the STKMKT sample splits (low and high STKMKT categories). The cash flow interaction with overall STKMKT shows a negative and insignificant coefficient. This indicates that stock market development does not have any role in the investment cash flow sensitivity coefficient and hence on reducing financing constraints.

The cash flow interaction with STKMKT sample split (low and high STKMKT categories) result shows firms in both low and high STKMKT countries show positive and significant cash flow coefficient meaning they are financially constrained. This result is the same as the FD sample splits result. The chi-square test shows no significant difference between the two groups of low and high STKMKT. Such result reaffirms the original results 
of cash flow interaction with overall STKMKT in that stock market development has no role in reducing financing constraints.

\section{Investment Equations with FININT Interactions}

The overall and sample split FININT regression results are the same as the FD result. The overall FININT regression result is significant and negative indicating the positive role of financial intermediary development in reducing financing constraints. Unlike the overall STKMKT regression which is insignificant, the overall FININT interaction is significant and negative.

The FININT sample split result shows again both low and high FININT groups are financially constrained. Furthermore, there is significant difference between these two coefficients reaffirming the positive role of financial intermediary development in reducing financing constraints.

\section{Discussion}

Merging the result of the entire three models (FD, STKMKT and FININT), the following summary points can be made. First, the results indicate financial development reduces financing constraints. This is possible because financial development mitigates information asymmetry and contracting imperfections, which create a wedge between the cost of internal and external finance. Such result is consistent with many authors cited in the literature (Rajan \& Zingales, 1998; Love, 2003; Becker and Sivandasany, 2010; Baum et al., 2011; Islam and Mozumdar, 2007; Khurana et al., 2006; Semenov, 2006). Increased access to finance can be one of the possible channels through which financial development can bring positive effective on the economic growth of a country.

Second, the positive role of financial development in reducing financing constraints is due to financial intermediary development rather than stock market development. This indicates that banks have better role in reducing information asymmetry. Besides, their role in monitoring and governance of firms is better than stock markets. Our results are consistent, but not exactly the same, with those found by Baum et al. (2011), Semenov (2006) and Tseng (2012). These authors found that firms in countries with dominantly market based financial system are more financially constrained than firms in bank based financial systems. Their result implies stock markets have a reduced role than banks in reducing firm financing constraints. Our result implies stock markets have no role at all. The difference between our results and theirs is the settings within which the studies are conducted. These studies are conducted in countries with developed stock markets where stock markets have some role in reducing financing constraints although not equal to that of banks. Our study is conducted in Africa where stock market development is at the infancy stage. Thus the no role of stock market is not that much surprising.

Third, all firms in the different financial development categories and its component classifications are financially constrained. This indicates the financial development in many African countries is too low, which is not surprising. As a result, even firms in countries with high financial development are constrained. This explanation is the same with the review of the African financial system explained by Allen et al. (2011), Misati \& Nyamongo (2011) and Yartey and Adjasi (2007).

Fourth, the chi-square result tells us firms in countries with low FD (FININT) are more financially constrained than firms in countries with high FD (FININT). This result reaffirms the positive role of financial development and financial intermediary development in reducing financing constraints found earlier. Thus the result is robust to alternative specification of overall financial development regression or sample splits.

\section{CONCLUDING REMARKS}

The role of financial development in economic growth is a highly contested topic in the economics and finance literature. One of the channels through which financial development can help a country's economic growth is by alleviating firm financing constraints. In this connection, the current study addressed the effect of financial development in reducing firm level financing constraints and this will provide some evidence towards the larger debate on finance-growth nexus. 
Financial development is measured as the sum of two components, stock market development and financial intermediary development, with each component measured using a set of their own variables. Financing constraints is measured using the sensitivity of investment to cash flow with higher sensitiveness interpreted as higher financing constraints. Data from 273 manufacturing firms from six African countries for a period of 7 years (2005-11) is used for the study. The African case is unique and important to investigate because no prior study addresses this issue in the region. Furthermore, the region has the lowest financial development by global standards and all type of firms are expected to bear the burden of financing constraints seriously. Checking such sort of hypothesis shed new light to the overall research tradition in this area.

The result of this study clearly indicates financial development help to reduce firm level financial constraints. One of the ways in which financial development reduce financing constraints is by mitigating information asymmetry and contracting imperfections. From the components of financial development, banking development is found to have a positive role in reducing firm financing constraints whereas stock market developments have no role. Such result may be due to the relatively bank dominated financial system of many African countries. Stock market development is at the infancy stage. It needs to be developed much to have any meaningful effect on financing firms' investment needs. The other interesting finding is that even firms in countries with high financial development (financial intermediary development) are financially constrained. This indicates that the African financial system is too weak even to the extent that such kinds of firms are highly constrained.

The overall implication of our findings is that policy makers shall give due attention to overall financial sector development. Specifically factors that shape financial development of a country need to be given emphasis. For instance La Porta et al. (1997) showed that legal system indicators such as the efficiency of the legal system, the rule of law, the risk of expropriation and corruption are one of the critical determinants of a country's financial development. Thus more political commitment is required to bring up those legal changes. Furthermore, in order to increase access to finance for firms the following improvements are needed in the African banking sector. Collateral requirements need to be lessened, relationship lending shall be promoted, the huge public sector presence needs to be reduced through privatizations, the banking sector should be liberalized and entry of foreign banks be allowed; regulatory measures need to be taken to create a competitive banking sector. Since the weak development of African stock markets is driving the insignificant results, more policy measures shall also be taken for stock market development.

\section{ACKNOWLEDGEMENTS}

I greatly appreciate the editor (Estelle van Tonder), anonymous reviewers and Daniel Makina (from University of South Africa) for constructive comments on the paper.

\section{AUTHOR INFORMATION}

Letenah Ejigu Wale is currently a post-doctoral fellow in University of South Africa (UNISA), South Africa. Before the current engagement, he was an Assistant Professor of Accounting and Finance at Bahir Dar University, Ethiopia. He taught graduate courses, advised Master thesis, and assumed administrative posts at a college level. He has published a couple of papers in peer reviewed national and international journals. He also consulted the public sector in Ethiopia on Security Market Development and Saving Mobilization Issues. His research interest includes financing constraints, financial inclusion and performance of microfinance institutions. E-mail: walele@unisa.ac.za; etalem2000@yahoo.com

\section{REFERENCES}

Aghion, P., Dewatripont, M., \& Rey, P. (1999). Competition, financial discipline and growth. Review of Economic Studies, 66(4), 825-852.

Allen, F. (1990). The market for information and the origin of financial intermediaries. Journal of Financial Intermediation, 1(1), 3-30.

Allen, F., \& Gale, D. (1999). Diversity of opinion and financing of new technologies. Journal of Financial Intermediation, 8(1-2), 68-89.

Allen, F., Otchere, I., \& Senbet, L.W. (2011). African Financial System: A Review. Review of Development 
Finance, 1(2), 79-113.

Alti, A. (2003). How sensitive is investment to cash flow when financing is frictionless? Journal of Finance, 58(2), $707-722$.

Bae, K.H., Chan, K., \& Ng, A. (2004). Investibility and Return Volatility. Journal of Financial Economics, 71 (2), 239-263.

Baum, C., Schäfer, D., \& Talavera, O. (2011). The impact of the financial system's structure on firms' financial constraints. Journal of International Money and Finance, 30 (4), 678-691.

Becker, B., \& Sivadasan, J. (2010). The Effect of Financial Development on the Investment Cash Flow Relationship: Cross Country Evidence from Europe. The B.E. Journal of Economic Analysis \& Policy, 10(1), Article 43

Bertrand, M., Schoar, A., \& Thesmar, D. (2007). Banking deregulation and industry structure: Evidence from the French banking reforms of 1985. Journal of Finance, 62(2), 597-628.

Bhide, A. (1993). The hidden costs of stock market liquidity. Journal of Financial Economics 34(1), 1-51.

Black, S.W., \& Moersch, M. (1998). Financial structure, investment and economic growth in OECD countries. In: Black, S.W., Moersch, M. (Eds.), Competition and Convergence in Financial Markets: The German and Anglo-American Models. North-Holland, New York, 157-174.

Bond, S., Elston, J.A., Mairesse, J., \& Mulkay, B. (2003). Financial factors and investment in Belgium, France, Germany, and the United Kingdom: a comparison using company panel data. The Review of Economics and Statistics, 85 (1), 153-165.

Boot, A.W.A., Greenbaum, S.J., \& Thakor, A. (1993). Reputation and discretion in financial contracting. American Economic Review, 83(5), 1165-1183.

Boyd, J.H., \& Prescott, E.C. (1986). Financial intermediary-coalitions. Journal of Economics Theory, 38(2(, 211232.

Cameroun, A.C., \& Trivedi, P.K. (2009). Microeconometrics using Stata. Stata Press, Texas

Carreira, C., \& Silva, F. (2013). Does Size, Age and Dividend Policy Provide Useful Measures of Financing Constraints? New Evidence from a Panel of Portuguese Firms.

Demirguc-Kunt, A., \& Maksimovic, V. (1998). Law, Finance and Firm Growth. Journal of Finance, 53(6), 21072131.

Diamond, D.W. (1984). Financial intermediation and delegated monitoring. Review of Economic Studies, 51(3), 393-414.

Fazzari, S.M., Hubbard, R.G., \& Petersen, B.C. (1988). Financing constraints and corporate investment. Brookings Papers on Economic Activity, 1988(1), 141-206.

George, R., Kabir, R., \& Qian, J. (2011). Investment cash flow sensitivity and financing constraints: Evidence from Indian Business Groups. Journal of Multinational Financial Management, 21(2), 69-88.

Greenwood, J., \& Jovanovic, B. (1990). Financial development, growth, and the distribution of income. Journal of Political Economy, 98(5), 1076-1107.

Guariglia, A. (2008). Internal financial constraints, external financial constraints and investment choice: Evidence from a Panel of UK firms. Journal of Banking \& Finance, 32(9), 1795- 1809.

Hellwig, M. (1991). Banking, financial intermediation, and corporate finance”. In: Giovanni, A., Mayer, C. (Eds.), European Financial Integration. Cambridge University Press, Cambridge, UK, 35-63.

Hubbard, R. (1998). Capital-market imperfections and investment. Journal of Economic Literature,36(1), 193-225.

Islam, S.S., \& Mozumdar, A. (2007). Financial Market Development and the Importance of Internal Cash: Evidence from International Data. Journal of Banking \& Finance, 31(3), 641-658.

Jensen, M., \& Murphy, K. (1990). Performance pay and top management incentives. Journal of Political Economy, 98(2), 225-263.

Jensen, M., \& Meckling, W.R. (1976). Theory of the firm, managerial behavior, agency costs and ownership structure. Journal of Financial Economics, 3(4), 305-360.

Kaplan, S., \& Zingales, L. (1997). Do investment-cash flow sensitivities provide useful measures of financing constraints? Quarterly Journal of Economics, 112(1), 169-216.

Khurana, I. K., Martin, X., \& Pereira, R. (2006). Financial development and the cash flow sensitivity of cash. Journal of Financial and Quantitative Analysis, 41(4), 787-807.

King, R. G., \& Levine, R. (1993). Finance and Growth: Schumpeter Might be Right. Quarterly Journal of Economics, 108(3), 717-737.

La Porta, R., Lopez-de-Silanes F., Shleifer A., \& Vishny R. (1997). Legal Determinants of External Finance. 
Journal of Finance, 52(3), 1131-1150.

Levine, R. (2005). Chapter 12 Finance and Growth: Theory and Evidence. Handbook of Economic Growth, 1(A), $865-934$.

Levine, R. (1997). Financial development and economic growth: views and agenda. Journal of Economic Literature, $35(2), 688-726$.

Love, I.(2003). Financial development and financing constraints: international evidence from the structural investment model. Review of Financial Studies, 16 (3), 765-791.

Merton, R.C., \& Bodie, Z. (2004). The design of financial systems: Towards a synthesis of function and structure. National Bureau of Economic Research Working Paper Number 10620.

Misati, R.N., \& Nyamongo, E.M. (2011). Financial Development and Private Investment in Sub-Saharan Africa. Journal of Economics and Business, 63(2), 139-151.

Modigliani, F., \& Miller M. (1958). The Cost of Capital, Corporate Finance, and the Theory of Investment. American Economic Review, 48(3), 261-297.

Morck, R., \& Nakamura, M. (1999). Banks and corporate control in Japan. Journal of Finance, 54(1), 319-340.

Myers, S.C., \& Majluf, N. (1984). Corporate financing and investment decisions when firms have information that investors do not have. Journal of Financial Economics, 13(2), 187-221.

Rajan, R.G., \& Zingales, L. (2003). Saving Capitalism from the Capitalists. Random House, New York.

Rajan, R.G., \& Zingales, L. (1999). Which capitalism? Lessons from the East Asian crisis. Journal of Applied Corporate Finance, 11(3), 40-48.

Rajan, R., \& Zingales, L.(1998). Financial Dependence and Growth. American Economic Review, 88(3), 559-586.

Robinson, J. (1952). The Generalization of the General Theory, in the rate of interest, and other essays. London: Macmillan, p.67- 142.

Roodman, D. (2009). How to do xtabond2: An Introduction to difference and system GMM in Stata. The Stata Journal, 9(1), 86-136.

Schumpeter, J. A. (1912). The Theory of Economic Development, trans. 1934, Harvard University Press, Cambridge, Mass.

Semenov, R. (2006). Financial system Financing constraints and Investment: Empirical analysis of OECD Countries. Applied Economics, 38(17), 1963-1974.

Shleifer, A., \& Vishny, R.W. (1997). A survey of corporate governance. Journal of Finance, 52(2), 737-783.

Starkey, R. (2010). Financial system development and economic growth in Selected African countries: Evidence from a panel cointegration analysis. Master's Thesis, Rhodes University, Grahamstown.

Stein, J.C. (1988). Takeover threats and managerial myopia. Journal of Political Economy, 96(1), 61-80.

Stiglitz J.E., \& Weiss, A. (1981). Credit information in markets with imperfect information. American Economic Review, 71(3), 393-410

Stiglitz, J.E. (2004). Capital-Market Liberalization, Globalization, and the IMF. Oxford Review of Economic Policy, 20(1), 57-71.

Stiglitz, J.E. (1985). Credit markets and the control of capital. Journal of Money, Credit and Banking, 17 (2), 133152.

Tseng, T. (2012). Will both direct financial development and indirect financial development mitigate investment sensitivity to cash flow? The Experience of Taiwan. Emerging Market Finance and Trade, 42 (2), 139-152.

Wurgler, J. (2000). Financial Markets and Allocation of Capital. Journal of Financial Economics, 58(1-2), 187-214.

Yartey, C. A., \& Adjasi, C. X. (2007). Stock Markel Development in sub-Saharan Africa: Critical Issues and Challenges. IMF Working Paper, WP/07/209. Washington, DC: International Monetary Fund. 